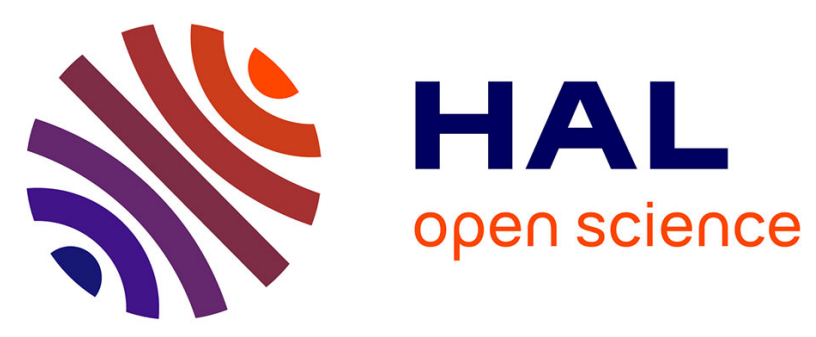

\title{
Effects of nest building by the dominant hunting ant, Ectatomma sp. 2 (E. ruidum complex), on Andean coffee plantations
}

Carlos Santamaría, Jean-Paul Lachaud, Inge Armbrecht

\section{To cite this version:}

Carlos Santamaría, Jean-Paul Lachaud, Inge Armbrecht. Effects of nest building by the dominant hunting ant, Ectatomma sp. 2 (E. ruidum complex), on Andean coffee plantations. Pedobiologia, 2020, 79, pp.150626. 10.1016/j.pedobi.2020.150626 . hal-03010526

HAL Id: hal-03010526

https://hal.science/hal-03010526

Submitted on 26 Nov 2020

HAL is a multi-disciplinary open access archive for the deposit and dissemination of scientific research documents, whether they are published or not. The documents may come from teaching and research institutions in France or abroad, or from public or private research centers.
L'archive ouverte pluridisciplinaire HAL, est destinée au dépôt et à la diffusion de documents scientifiques de niveau recherche, publiés ou non, émanant des établissements d'enseignement et de recherche français ou étrangers, des laboratoires publics ou privés. 


\section{Effects of nest building by the dominant hunting ant, Ectatomma sp. 2 (E.} ruidum complex), on Andean coffee plantations

.

Carlos Santamaría ${ }^{1}$, Jean-Paul Lachaud ${ }^{2,3}$, Inge Armbrecht ${ }^{1}$

${ }^{1}$ Departamento de Biología, Universidad del Valle, Cali, Colombia

${ }^{2}$ Departamento de Conservación de la Biodiversidad, El Colegio de la Frontera Sur, Chetumal 77014, Quintana Roo, Mexico

${ }^{3}$ Centre de Recherches sur la Cognition Animale, Centre de Biologie Intégrative, Université de Toulouse UPS, CNRS-UMR5169, UPS, 31062 Toulouse Cedex 09, France

Keywords: ant bioturbation, Ectatomma ruidum sp. 2, shaded vs. sun coffee, ecological function, plant growth.

\section{Abstract}

Soil removal by ants when building or adapting their nests generates ecological changes within the soil and on its surface, impacting both soil physical properties and plant growth. Ectatomma sp. 2 (E. ruidum complex) is a dominant hunting ant in numerous neotropical agricultural systems; however, its bioturbation impact on agroecosystems of economic importance, such as coffee, has not been studied. We evaluated it on coffee seedlings in Andean plantations of Colombia. Sixty colonies of this ant (30 in sun coffee, 30 in shaded coffee) were added within enclosed experimental units (EUs) containing coffee seedlings, and compared with their respective controls without ants. On average, dry soil removal by colony was $104.4 \mathrm{~g}$ during the two months experimental period ( $1.6 \mathrm{~g} \mathrm{day}^{-1}$ colony $\left.^{-1}\right), 13$ times higher than in controls. A conservative estimate of their global bioturbation impact was calculated at between 59.3 and $203.1 \mathrm{~kg}$ dry soil $\mathrm{ha}^{-1}$, considering only two months of digging activity year ${ }^{-1}$ colony $^{-1}$, a likely underestimation of the actual digging activity of this species. Positive effects of the presence of ants were found on several plant growth variables and on soil microporosity in shaded coffee plantations. Taking into consideration only the 14 colonies that were fully active until the end of the experiment, dry soil removal was on average $228.8 \mathrm{~g}\left(3.5 \mathrm{~g} \mathrm{day}^{-1}\right.$ colony $\left.^{-1}\right)$ during the two months experimental period 
32 and coffee seedling growth in these EUs was significantly higher than in controls, 33 indicating that, at the global scale, our bioturbation estimate could be higher under less 34 restricted natural conditions and higher nest densities as found in other regions. Ectatomma 35 ruidum sp. 2 appears as a functional agent in agroecosystems due to its ubiquity and its 36 high bioturbation impact during the nest excavation period of activity, providing support 37 services in agroecosystems and neotropical natural systems. 


\section{1 | INTRODUCTION}

Ants are the most diverse group of social insects (Bolton et al., 2007; Ward, 2009).

However, of the more than 16,000 valid species of ants currently recognized (AntWeb,

2019), very few species have been thoroughly studied with regard to their nest structure and their impact on their environment. Most ant nests are hypogeous and their building can result in the removal of considerable volumes of soil (Hölldobler \& Wilson, 1990). Due to their activity and abundance in agroecosystems and natural systems, some species may impact deeply ecological processes (Folgarait, 1998), but our understanding of the principal ecosystemic services supplied by ants is still very limited (Del Toro et al., 2012). Two of these ecosystem services are particularly important: bioturbation resulting in soil turnover, both at the superficial and subsurface levels, where ants act as ecosystem engineers (Lobry de Bruyn \& Conacher, 1994; Lavelle et al., 2006; Tschinkel, 2015; Tschinkel \& Seal, 2016), and changes in soil physical properties, which, in turn, may provide benefits for neighbouring plants (Lobry de Bruyn \& Conacher, 1990; Eldridge et al., 2009).

Bioturbation by ants is evidenced through soil mounds deposited while subterranean nest construction or enlargement is carried out by workers. This process of soil excavation for nest construction results in the vertical movement and redistribution of organic and inorganic materials through the soil profile (Folgarait, 1998). For example, the fungusgrowing ant Atta laevigata builds between nearly 1,150 and 7,900 chambers, probably moving more than one million $\mathrm{cm}^{3}$ soil per mature nest (Moreira et al., 2004). Similarly, in two different coastal ecosystems of eastern and southeastern Sweden, ant bioturbation essentially performed by Lasius niger and Formica exsecta reached between 300-400 kg ha $^{-1} \mathrm{y}^{-1}$ (Persson et al., 2007), while in New Mexico (USA), the average quantity of soil moved to the surface by a whole ant assemblage reached approximately $842 \mathrm{~kg} \mathrm{ha}^{-1}$ for the two month period (August-September) of surface activity only (Whitford et al., 1986). In arid soils of Australia, nests of Aphaenogaster barbigula have an average density of entrances of $88,000 \mathrm{ha}^{-1}$, and exert a global bioturbation effect of 3,360 $\mathrm{kg} \mathrm{ha}^{-1} \mathrm{y}^{-1}$, demonstrating the importance of just one of the ant species in this region in terms of soil removal (Eldridge \& Pickard, 1994). Another species of the same genus, A. longiceps, 
70 exerts a bioturbation effect of $8,410 \mathrm{~kg} \mathrm{ha}^{-1} \mathrm{y}^{-1}$ which can reach the extraordinary high

71 values of $68,380 \mathrm{~kg} \mathrm{ha}^{-1} \mathrm{y}^{-1}$ in sandy soil (Richards, 2009).

72

Apart from changing the physical and chemical properties of the soil, bioturbation

generates a higher infiltration of water in the soil, both through nest entrances at the

75 surface, and as a result of increased macroporosity. For example, in Australian zones where nests of $A$. barbigula were present in high densities, water infiltration averaged $23.3 \mathrm{~mm}$ $\min ^{-1}$, i.e. about four times more than in zones without nests of this species (Eldridge, 1993). In Australia, Evans and coauthors found no effect of ant nesting in agricultural areas; however, two years later they found three times as much water infiltration in agricultural areas where ants nested in than in areas without ant nests (Evans et al., 2011).

Physical changes to the soil, associated with the additional aggregation of organic material gathered by ants and deposited inside or outside their nests (both of plant and animal origins), impact on its water-holding capacity and soil fertility (Farji-Brener \& Werenkraut, 2017). Soil changes in the vicinity of the nests or mounds of numerous ant species also have a positive influence on the growth of neighbouring plants (Shukla et al., 2018). Even the nests of some invasive ant species, such as Solenopsis invicta can exert positive effects on plant growth (Lafleur et al., 2005) and in some dominant ants with longlasting mounds, such as Lasius flavus in the Czech Republic, positive effects on mound vegetation can last several years after the disappearance or the substitution of the original ant occupant (Kovář et al., 2001).

In the Neotropics, Ectatomma ruidum sp. 2 (E. ruidum complex) is a dominant ground-dwelling predatory ant species of great interest due to its functional importance in 
101 Although E. ruidum sp. 2 nest density tends to be high, the role of this species on

102 bioturbation, soil porosity and water infiltration through the surface nest entrances has not

103 been documented. It is to be expected that nest galleries that connect nest chambers with

104 the surface could improve water movement through the soil, as has been documented with

105 termites and other ant species (Lobry de Bruyn \& Conacher, 1990). Furthermore, E. ruidum

106 sp. 2 can exhibit high predation rates (several million prey $\mathrm{ha}^{-1} \mathrm{y}^{-1}$, see Lachaud et al.

107 (1996)) thus adding large amounts of organic material to their nests that enhances soil

108 fertility around the nest area. Such effects can occur during the colony life cycle and after

109 nest abandonment. Due to the characteristics exhibited by E. ruidum sp. 2 in

110 agroecosystems, such as high nest density ha ${ }^{-1}$, high predation rates, and high

111 myrmecochorous activity (Lachaud et al., 1996; Gutierrez-Rapalino \& Domínguez-Haydar,

112 2017), this species has been considered as an important functional agent in neotropical

113 agroecosystems and natural systems (Schatz \& Lachaud, 2008; Domínguez-Haydar \&

114 Armbrecht, 2011). In order to examine whether field data support the significant ecological

115 function played by this ant species, we evaluated, for the first time in coffee

116 agroecosystems, the role of E. ruidum sp. 2 in bioturbation through measuring soil removal

117 activity and the effect of this removal on both water infiltration and growth of neighbouring

118 coffee seedlings over a relatively short time span. We hypothesized that the presence of

119 excavating colonies of E. ruidum sp. 2 causes significant changes both in soil and

120 neighboring plants. Therefore, our objective was to test whether the presence of E. ruidum

121 sp. 2 results in higher bioturbation, more changes in soil physical properties, and faster

122 growth of coffee seedlings than equivalent areas without colonies of this ant.

123

$124 \quad 2$ | MATERIALS AND METHODS

125

126

2.1 | Study area

127 
128 The study was carried out in the Southwestern region of the Colombian Andes, in the 129 municipality of Caldono, Department of Cauca $\left(2^{\circ} 49^{\prime} \mathrm{N}, 76^{\circ} 32^{\prime} \mathrm{W}\right)$. The mean annual 130 temperature is $21.5^{\circ} \mathrm{C}$, with a total annual rainfall of $2,191 \mathrm{~mm}$ distributed in a bimodal 131 pattern with two high peaks in April-May and October-November. Altitude varies between 1321,000 and 2,000 m.a.s.l. The area is predominantly agricultural and coffee production has 133 increased over the past years, generally in the form of 1-20 ha small farms. The Department 134 of Cauca is the sixth coffee producer in Colombia covering 74,000 hectares (FNC, 2010). 135 In 2009, shaded coffee plantations dominated the area, covering about $72 \%$ of the 136 cultivated area, the remaining 20,500 ha being covered by coffee plantations without shade 137 (FNC, 2010). We define "sun" coffee plantation as an uncovered or "shadeless" coffee 138 crop, in which there are no trees surrounding the coffee bushes; a "shaded" coffee 139 plantation consists of coffee bushes intermingled with 10-25 m height trees such as Inga 140 spp., Erithrina spp., Cordia alliodora, Persea americana, and Citrus sinensis, among 141 others (Fig. 1).

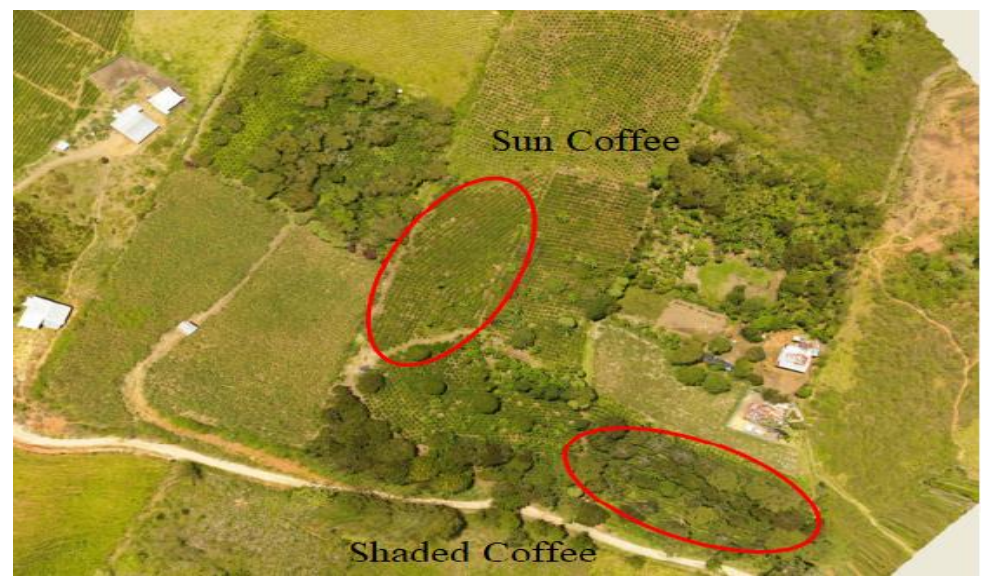

142 Fig. 1. Aerial image showing an example of both, the sun coffee and shaded coffee 143 management plots ("farm") where experimental units with and without colonies of the ant

144 Ectatomma ruidum complex sp. 2 were installed. The farms were located in the town of El 145 Rosal, municipality of Caldono, Cauca - Colombia.

\section{$147 \quad 2.2 \mid$ Experimental design}

149 Between August 2016 and May 2017, 20 experimental coffee plots (which will be referred 150 to as "farms") were randomly chosen, 10 under shade and 10 under sun, all of them at 
151 1,450 m.a.s.l. The independence of the plots was assumed using the following arguments:

152 1) neighbouring plots around each farm differed in management: for example, farms were 153 separated by a tomato crop, a family orchard or a pasture; 2) if there was no other different 154 management, farms were separated by at least $100 \mathrm{~m}$; 3) sun and shaded coffee should form 155 a mosaic in the landscape, that is, sun and shaded farms should be intermingled over the 156 landscape and not grouped.

In each farm, six bottomless polymer mesh baskets, or experimental units (which 159 will be referred to as "EUs"), $50 \mathrm{~cm}$ in diameter and $30 \mathrm{~cm}$ in height (Fig. 2), were 160 installed. Each EU was separated by a distance of 1 metre. The first $15 \mathrm{~cm}$ of each EU was 161 buried within the soil and the remaining $15 \mathrm{~cm}$ was left exposed above ground and isolated 162 from walking insects by applying Tanglefoot ${ }^{\circledR}$ insulator around the top edges. Two coffee 163 seedlings (Coffea arabica-variety caturra) in a state of "chapola" with the bare root 164 ("chapola" are sprouted seedlings, approximately $5 \mathrm{~cm}$ high, that have produced the first 165 pair of primary leaves) were planted inside each EU (Fig. 2). Three weeks after the 166 chapolas were planted, three EUs were randomly assigned as "treatment" and three as 167 “control” for each farm.

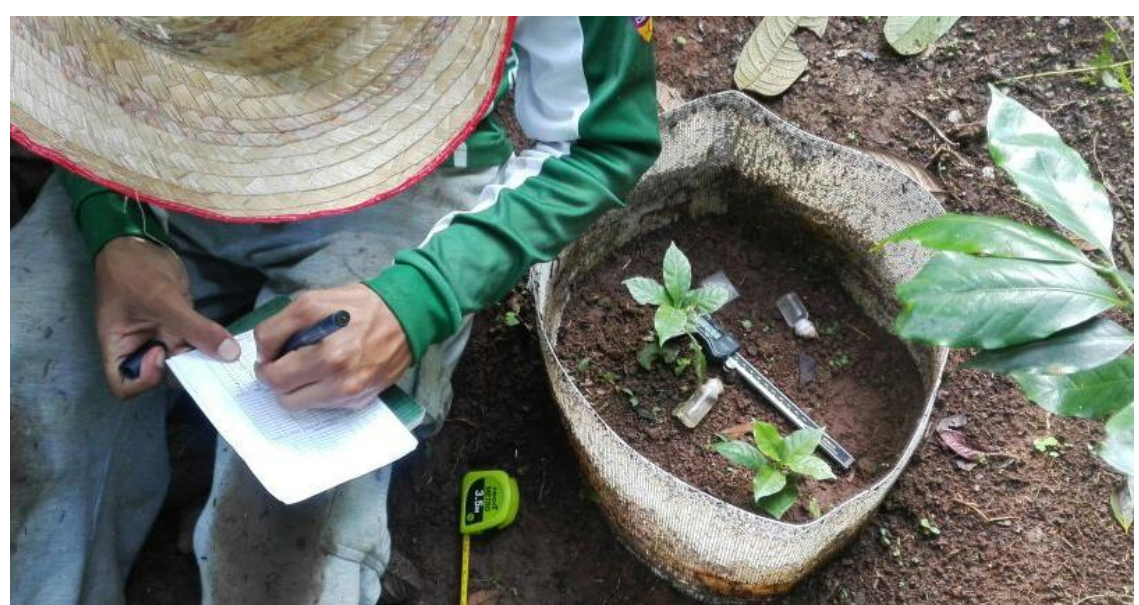

168 Fig. 2. Photo showing an experimental unit (EU) consisting of an exclusion basket, with or 169 without an E. ruidum sp. 2 colony, used both in shaded and sun coffee plantations. 
174 between 10-20 larvae and five pupae. No ants were added to the control EUs. Ant colonies 175 were fed with Acheta domesticus crickets or tuna-in-oil $\left(1 \mathrm{~cm}^{3}\right)$ every two days, and with 176 honey and water two times a week. Control EUs were supplied with the same food as 177 treatment EUs, and any food remains were removed from both EUs every other day.

\subsection{Soil removal}

180

181 Once ant colonies had been added in each treatment EU, the soil removed by E. ruidum sp.

1822 workers (Fig. 3) during the process of building their nest was collected every two days 183 over a period of 66 days. The soil was removed by gentle brushing with the aid of a spatula. 184 Each collection action took one whole day between 7:00AM and 5:00PM. The procedure 185 was always conducted in the same order, alternating treatment and control EUs, and also 186 shaded and sun coffee farms. The soil collected in the control EUs allowed an assessment 187 of the action of ant species other than E. ruidum as well as additional excavating 188 invertebrates present in the EUs (mostly earthworms, Gryllidae, Gryllotalpidae, spiders, 189 and Scarabaeidae larvae). Soil material was introduced in letter-sized paper envelopes and 190 the samples were immediately oven dried at $45^{\circ} \mathrm{C}$ for 24 hours and weighed on a high191 resolution precision balance (Adventure ${ }^{\mathrm{TM}}$ Ohaus GLP/GMP) using a $50 \mathrm{~mL}$ beaker.

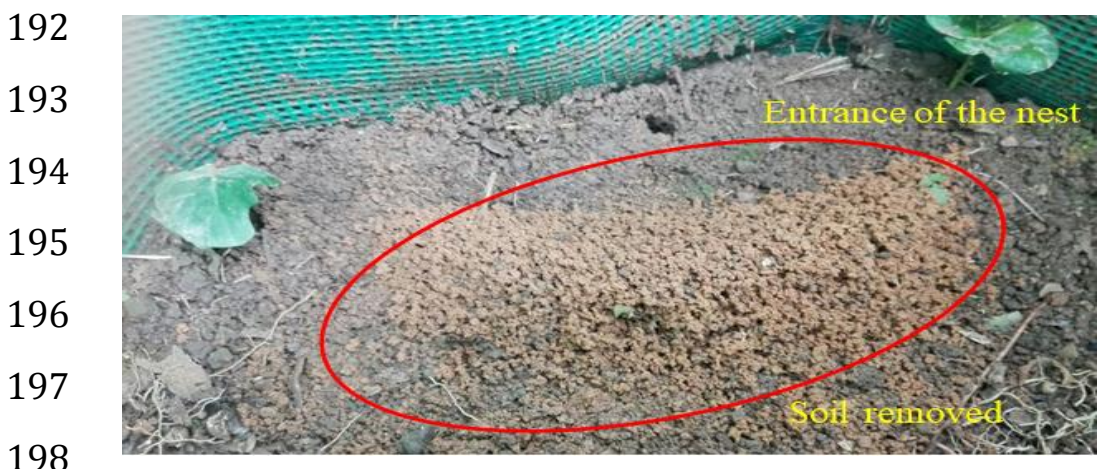

199 Fig. 3. Example of soil particles removed during nest excavation by E. ruidum sp. 2 200 workers in a treatment EU.

201

\section{$202 \quad 2.4 \mid$ Plant growth variables}

203 
204 Plant height was measured from the base of the ground to the top of the plant (apical

205 meristem without including the leaf, which will be referred to as "length"). The diameter of

206 the stem was measured $1 \mathrm{~cm}$ above ground level using a Mitutoyo ${ }^{\circledR} 0.01 \mathrm{~mm}$ precision

207 digital calibrator. All measurements were taken every two weeks (six measurements in

208 total), for three months, the first measurement being recorded on the day the "chapola" was

209 planted. All measurements were taken on the same day and, for logistical reasons, always

210 started at the same farm. The length of the seedling from the main root tip toward the apical

211 meristem, plant dry weight and root dry weight were recorded at the end of the experiment.

\section{$213 \quad 2.5 \mid$ Soil infiltration}

214

215 Water infiltration was measured twice for each EU: on day one, when ant colonies were

216 introduced to treatment EUs (T1) and two months later (T2) at the end of the experiment

217 (T1: zero day elapsed, and T2: 66 days elapsed). Measurements were taken using disk

218 infiltrometers (Mini Disk Infiltrometer, Decagon Devices, Inc.) placed simultaneously in

219 the control and treatment EUs; these measurements were taken in all of the 120 EUs of the

220 study. The infiltrometer was placed vertically on the soil surface, $10 \mathrm{~cm}$ from the nest

221 entrance in the treatment, and in the center of the basket in the control EUs. The upper and

222 lower chambers of the infiltrometers were filled with water. The upper chamber serves to

223 control suction and the lower chamber stores the water for infiltration. The water was

224 passed through a porous stainless-steel disk $0.3 \mathrm{~cm}$ high and $4.5 \mathrm{~cm}$ in diameter, located at

225 the end of the lower chamber, and using a suction rate of $2.0 \mathrm{~cm}$. The initial volume of the

226 water was $85 \mathrm{~cm}^{3}$ and, in accordance with the type of soil in the EU, the time interval for

227 manual readings was adjusted to $30 \mathrm{~min}$. The initial volume of water and the volume of

228 filtered water were tabulated (in $\mathrm{mL}$ ), recording volumes at regular interval times of $30 \mathrm{~s}$

229 for a total of 30 min per EU. Cumulative infiltration over time for each EU was calculated

230 using Equation 1 (Philip, 1957):

231

232

233

$$
I=C_{1} t+C_{2} \sqrt{t}
$$

Where $\mathrm{I}$ is the cumulative infiltration, $\mathrm{C}_{1}$ is the curve of the infiltration accumulation vs. time, $\mathrm{C}_{2}$ is the relation to the absorption of the soil and $\mathrm{t}$ is the time. 
235

236

237

238

239

240

241

242

243

244

245

246

247

248

249

250

251

252

253

254

255

256

257

258

259

260

261

262

263

264

265

\section{6 | Physical properties of the soil}

Various physical parameters of the soil were measured at the end of the experiment: apparent density, macropore drainable porosity, micropore field capacity, total porous space, and humidity of the sampling. To achieve this, samples were taken from the first 10 $\mathrm{cm}$ top soil layer of each EU, $10 \mathrm{~cm}$ from the nest entrance in the treatment EUs and in the centre of the control EUs, filling a metallic cylinder with $50 \mathrm{~g}$ of soil extracted from each EU. Analyses were carried out at the Environmental Physics Laboratory at the Universidad del Valle (ILAMA Research Group). The NTC 5167 gravimetric method was used for all of the fore-mentioned parameters.

\section{7| Statistical analysis}

For all analyses, both land use (sun vs. shaded coffee) and ant presence (with vs. without $E$. ruidum sp. 2) were considered a fixed factor, while "farm" was a random factor. In all cases we examined the possible interaction between the factors in relation to each of the response variables measured in the experiment. A deviance analysis was carried out associated with a generalized linear model (GLM) with a Poisson distribution error term, and adding the "farm" block factor to control for possible variability between one farm and another. One model was run with homogeneous variances and one model with heterogeneous variances. The second model (heterogenous variances) was selected according to the AIC and BIC information criteria.

In order to determine whether measurement time influenced plant growth variables, we considered it in the model, together with land use and ants presence, as fixed factors. In this case, the possible interaction among the three factors (time, land use, and ant presence), and their possible effect on plant growth variables (response variables: stem diameter and seedling length) were examined. For this, a deviance analysis was carried out associated with a mixed linear model (LMM) with heterogeneous variances according to the AIC and BIC information criteria, taking for this case the "basket" as the random factor and the "farm" factor as a block within the model. 
266 Statistical analyses were carried out using the R distribution program, version 3.4.0 267 (R Development Core Team, 2017), determining statistical differences to a 5\% significant 268 level.

\section{3 | RESULTS}

\subsection{Soil removal}

273

The digging activity of E. ruidum sp. 2 resulted in a statistically significant higher amount of soil removal in the treatment EUs when compared with the control EUs over the complete experiment. On average, over the 66 days of recording, the cumulative soil removal in each EU containing an E. ruidum sp. 2 colony was $112.6 \pm 66.3$ g dry soil vs. $8.2 \pm 14.4 \mathrm{~g}$ in each control EU (Fig. 4B). On average, each E. ruidum sp. 2 colony of approximately 70 workers removed $104.4 \mathrm{~g}$ dry soil during the two month period of the experiment ( $1.6 \mathrm{~g}$ day $^{-1}$ colony $\left.^{-1}\right)$, almost 13 times more than the global soil removal performed by other invertebrates (arthropods, annelids or other ant species) present on an equivalent surface during the same period of time. On average, soil removal in sun coffee was $114.7 \pm 65.7 \mathrm{~g}$ per EU vs. $106.3 \pm 68.4 \mathrm{~g}$ in shaded coffee, and neither land use nor farm variables had any statistically significant effect on soil removal $\left(\chi^{2}=0.436\right.$ and 0.093 , respectively; N.S.) (Fig. 4A). However, because soil removal gradually decreased as the experiment continued (Fig. 5) due, in part, to the death of various colonies and the low soil removal activity of numerous other colonies, these results underestimate the real bioturbation impact of E. ruidum sp. 2 in coffee plantations. Only 14 E. ruidum sp. 2 (six in sun coffee, eight in shaded coffee) were still fully active at the end of the experiment; however, given that the EUs could not be disturbed during data collection, the final absence of a colony could only be established at the end of the experiment. Out of the 60 colonies which have been added at the beginning of the experiment, 23 demonstrated very limited activity. Twenty three other colonies almost completely disappeared, probably due to either

296 the colonies in the EUs. The cumulative soil removal during the 66 days experimental 
297 period for the 14 EUs that were fully active until the end of the experiment, reached 237.0 $298 \pm 44.7 \mathrm{~g}$ of dry soil per colony $(267.3 \pm 29.6 \mathrm{~g}$ in sun coffee vs. $214.3 \pm 41.3 \mathrm{~g}$ in shaded 299 coffee). In fact, taking into account soil removal by other invertebrates ( $8.2 \mathrm{~g}$ per EU), each 300 one of these 14 E. ruidum sp. 2 colonies removed on average $228.8 \mathrm{~g}$ dry soil (Fig. 5A), 301 that is $3.5 \mathrm{~g} \mathrm{day}^{-1}$ colony $^{-1}$, more than twice the previous assessment.

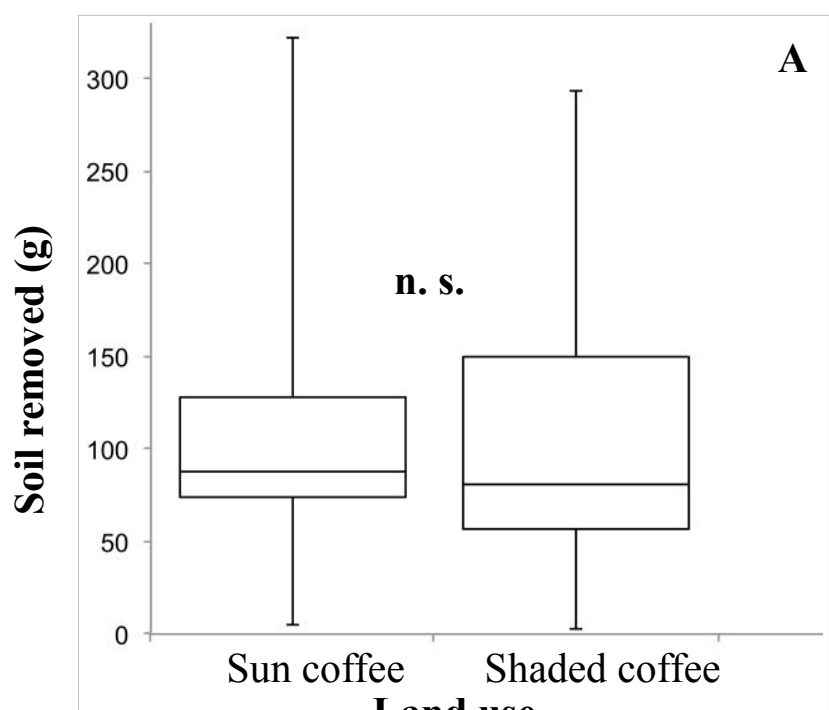

Land use
A

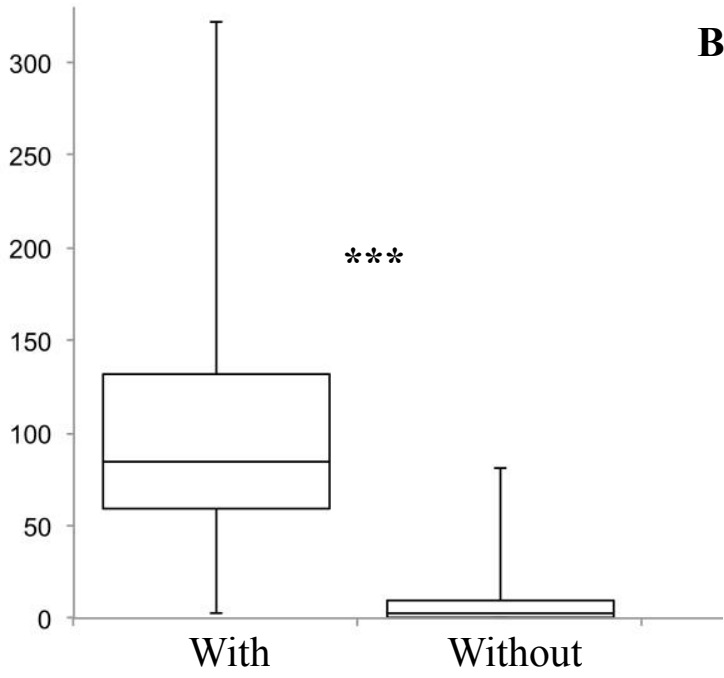

E. ruidum sp. 2

Fig. 4. Box diagrams of cumulative soil removal during the experiment: A) in sun and shaded coffee with E. ruidum sp. 2 (n $=30$ for each land use), B) in all the EUs with or without $E$. ruidum sp. 2 ( $\mathrm{n}=60$ for each treatment) (n.s.: not significant; ***: $P=2 \mathrm{e}-16$ ). Vertical bars show minimum and maximum values.

The GLM analysis to evaluate differences in the weight of soil removed at each collection event (every two days) in the EUs with or without E. ruidum sp. 2 revealed that the time of collection played a significant role. In all nests, soil removal was higher at the start of the experiment and decreased significantly as the experimental period progressed. Such effect was particularly evident for the 14 colonies which were active until the end of the experiment $\left(\chi^{2}=670.093 ; p<<2 \mathrm{e}-16\right)$ (Table 1; Fig. 5A), but was also discernible in the remaining 23 colonies which showed very discrete soil removal activity $\left(\chi^{2}=165.395\right.$; $p<<2.2 \mathrm{e}-16$ ) (Fig. 5B) and even in the 23 colonies which disappeared during the course of the experiment $\left(\chi^{2}=126.446 ; 2 \mathrm{e}-16\right)$ (Fig. 5C). The average quantity of soil removed was always significantly higher during the first weeks of the experimental period, regardless of 
328 whether the colonies were active until the end of the experiment (Table 1), remaining at a 329 very reduced level after five weeks for all colonies. There was no significant effect related 330 to the factor "land use" (that is, between sun and shaded coffee plantations) $\left(\chi^{2}=0.037\right.$;

331 N.S.), contrary to the "farm" factor which was significant $\left(\chi^{2}=47.995 ; p<<0.05\right)$.
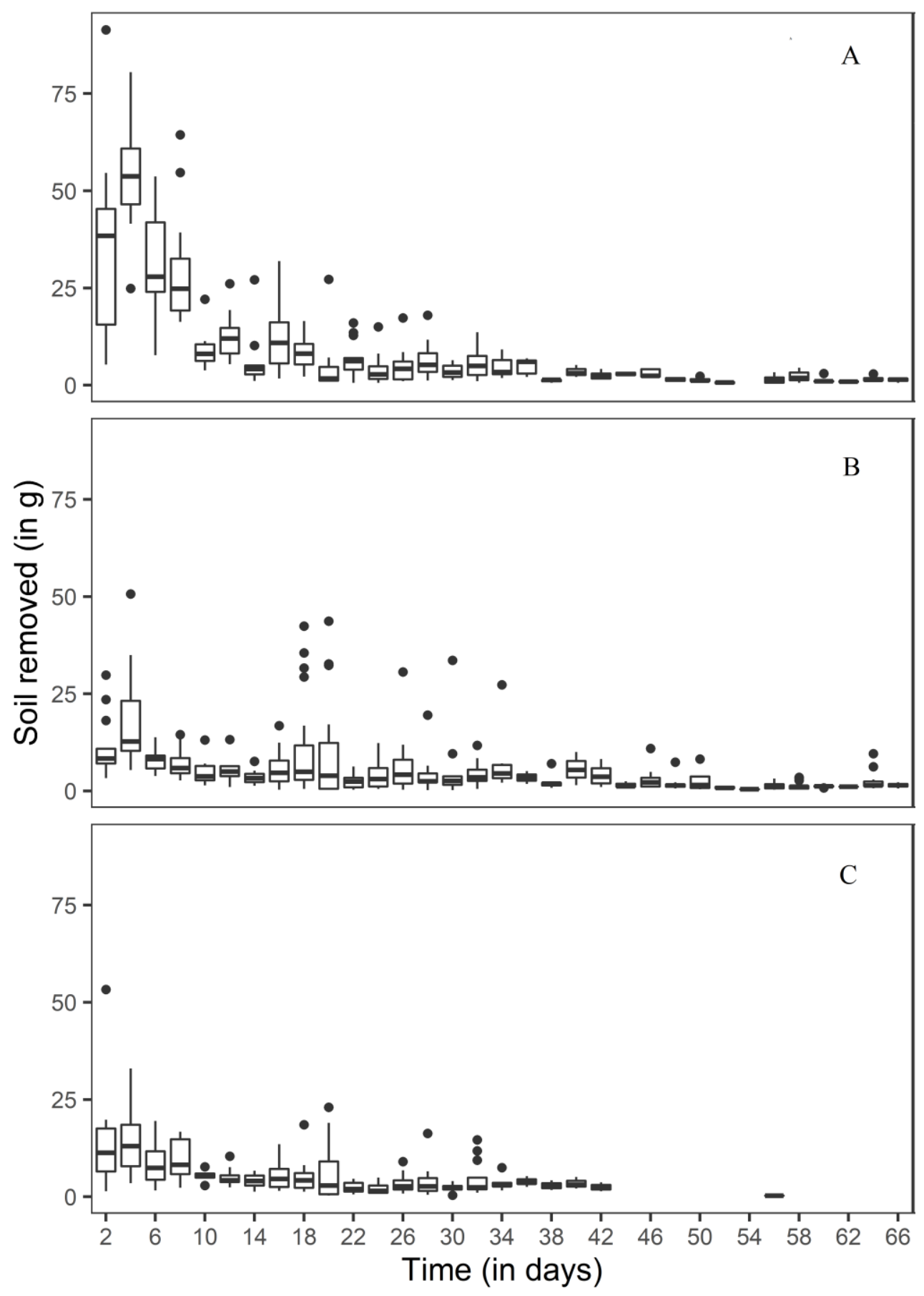
335 Fig. 5. Box diagrams of soil removal by E. ruidum sp. 2 in all coffee plots during the two 336 month experimental period. A) Soil removal in the 14 treatment EUs where colonies 337 remained active until the end of the experiment; B) Soil removal in the 23 treatment EUs 338 where colonies showed low activity until the end of the experiment; C) Soil removal in the 33923 treatment EUs where colonies did not remain active until the end of the experiment. $\bullet$ : outliers. Vertical bars show minimum and maximum values.

Table 1. Average and standard error of soil (in g) removed weekly by E. ruidum sp. 2

343 colonies during the first four weeks of the experimental period, according to the activity 344 level of the colonies.

\begin{tabular}{lcccc}
\hline & 1st week & 2nd week & 3rd week & 4th week \\
\hline $\begin{array}{l}\text { Colonies which were active until the } \\
\text { end of the experiment }(\mathrm{n}=14)\end{array}$ & $151.2 \pm 36.7$ & $30.5 \pm 15.6$ & $20.1 \pm 11.2$ & $17.9 \pm 6.8$ \\
$\begin{array}{l}\text { Colonies which presented very } \\
\text { discrete soil removal activity }(\mathrm{n}=23)\end{array}$ & $28.9 \pm 27.7$ & $11.2 \pm 6.2$ & $24.3 \pm 26.3$ & $14.3 \pm 14.0$ \\
$\begin{array}{l}\text { Colonies which disappeared over the } \\
\text { course of the experiment }(\mathrm{n}=23)\end{array}$ & $27.5 \pm 23.9$ & $7.7 \pm 6.9$ & $9.0 \pm 9.5$ & $9.0 \pm 9.1$ \\
\hline
\end{tabular}

346

3.2 Seedling growth and physical properties of the soil

Taking into account all the experimental units, the statistical analyses showed significant differences in the majority of the measured plant growth variables (seedling length, seedling length from the main root tip, root dry weight) when land use was considered, but none related to the presence or absence of E. ruidum sp. 2, or the factor 'farm' (Table 2).

353 Water infiltration (T2) at the end of the experiment and macropore drainable porosity were 354 higher in sun coffee than in shaded coffee, while microporous field capacity was lower 355 (Table 2). However, presence or absence of E. ruidum sp. 2 colonies had no significant 356 effect on the physical properties of the soil.

358 Table 2. Statistical results (A) and description of plant growth response variables (B).

359 Table 2A: Deviance analysis for all the variables measured at the end (except T1 
360 infiltration) of the experiment within the EUs located in sun and shaded coffee plantations.

361 (*): Significant difference at the 0.05 level threshold. Table 2B: Average and standard

362 deviation of plant growth variables and soil physical properties; $n=60$ for all cases.

$363 \quad(\mathrm{~A})$

\begin{tabular}{|c|c|c|c|c|c|c|c|c|}
\hline \multirow[t]{2}{*}{ Variable } & \multicolumn{2}{|c|}{$\begin{array}{c}\text { Land use } \\
\text { (shaded/sun coffee) }\end{array}$} & \multicolumn{2}{|c|}{$\begin{array}{l}\text { Presence/absence of } \\
\text { E. ruidum sp. } 2\end{array}$} & \multicolumn{2}{|c|}{$\begin{array}{l}\text { Interaction Land use } \\
\text { and Presence/absence } \\
\text { of } E \text {. ruidum sp. } 2\end{array}$} & \multicolumn{2}{|c|}{ Farm (block) } \\
\hline & Statistics & p-value & Statistics & p-value & Statistics & p-value & Statistics & p-value \\
\hline $\begin{array}{l}\text { Length of the } \\
\text { seedling }(\mathrm{cm})\end{array}$ & $\begin{array}{l}\chi_{(d f=1)}^{2}= \\
5.695\end{array}$ & $0.017^{*}$ & $\begin{array}{l}\chi_{(d f=1)}^{2}= \\
2.268\end{array}$ & 0.132 & $\begin{array}{l}\chi_{(d f=1)}^{2}= \\
0.365\end{array}$ & 0.546 & $\begin{array}{l}\chi_{(d f=19)}^{2}= \\
0.709\end{array}$ & 0.399 \\
\hline $\begin{array}{l}\text { Length of the } \\
\text { seedling from main } \\
\text { root tip }(\mathrm{cm})\end{array}$ & $\begin{array}{l}\chi_{(d f=1)}^{2}= \\
5.016\end{array}$ & $0.025^{*}$ & $\begin{array}{l}\chi_{(d f=1)}^{2}= \\
2.478\end{array}$ & 0.115 & $\begin{array}{l}\chi_{(d f=1)}^{2}= \\
0.527\end{array}$ & 0.468 & $\begin{array}{l}\chi_{(d f=19)}^{2}= \\
1.729\end{array}$ & 0.189 \\
\hline Plant dry weight (g) & $\begin{array}{l}\chi_{(d f=1)}^{2}= \\
2.249\end{array}$ & 0.134 & $\begin{array}{l}\chi_{(d f=1)}^{2}= \\
0.461\end{array}$ & 0.497 & $\begin{array}{l}\chi_{(d f=1)}^{2}= \\
0.829\end{array}$ & 0.362 & $\begin{array}{l}\chi_{(d f=19)}^{2}= \\
0.398\end{array}$ & 0.528 \\
\hline Root dry weight (g) & $\begin{array}{l}\chi_{(d f=1)}^{2}= \\
8.474\end{array}$ & $0.004 *$ & $\begin{array}{l}\chi_{(d f=1)}^{2}= \\
1.198\end{array}$ & 0.274 & $\begin{array}{l}\chi_{(d f=1)}^{2}= \\
0.257\end{array}$ & 0.612 & $\begin{array}{l}\chi_{(d f=19)}^{2}= \\
0.042\end{array}$ & 0.838 \\
\hline Stem diameter $(\mathrm{mm})$ & $\begin{array}{l}\chi_{(d f=1)}^{2}= \\
2.884\end{array}$ & 0.089 & $\begin{array}{l}\chi_{(d f=1)}^{2}= \\
0.081\end{array}$ & 0.776 & $\begin{array}{l}\chi_{(d f=1)}^{2}= \\
0.148\end{array}$ & 0.701 & $\begin{array}{l}\chi_{(d f=19)}^{2}= \\
2.336\end{array}$ & 0.126 \\
\hline $\mathrm{T} 1$ infiltration (ml) & $\begin{array}{l}\chi_{(d f=1)}^{2}= \\
0.247\end{array}$ & 0.619 & $\begin{array}{l}\chi_{(d f=1)}^{2}= \\
0.163\end{array}$ & 0.687 & $\begin{array}{l}\chi_{(d f=1)}^{2}= \\
0.213\end{array}$ & 0.644 & $\begin{array}{l}\chi_{(d f=19)}^{2}= \\
0.475\end{array}$ & 0.491 \\
\hline T2 infiltration (ml) & $\begin{array}{l}\chi_{(d f=1)}^{2}= \\
8.212\end{array}$ & $0.004 *$ & $\begin{array}{l}\chi_{(d f=1)}^{2}= \\
0.268\end{array}$ & 0.604 & $\chi^{2}=0.136$ & 0.713 & $\begin{array}{l}\chi_{(d f=19)}^{2}= \\
0.406\end{array}$ & 0.524 \\
\hline $\begin{array}{l}\text { Apparent density } \\
\left(\text { g.cc }{ }^{-1}\right)\end{array}$ & $\begin{array}{l}\chi_{(d f=1)}^{2}= \\
1.495\end{array}$ & 0.221 & $\begin{array}{l}\chi_{(d f=1)}^{2}= \\
0.010\end{array}$ & 0.919 & $\chi^{2}=0.021$ & 0.886 & $\begin{array}{l}\chi_{(d f=19)}^{2}= \\
0.048\end{array}$ & 0.827 \\
\hline $\begin{array}{l}\text { Total porous space } \\
(\%)\end{array}$ & $\begin{array}{l}\chi_{(d f=1)}^{2}= \\
1.449\end{array}$ & 0.229 & $\begin{array}{l}\chi_{(d f=1)}^{2}= \\
0.005\end{array}$ & 0.942 & $\begin{array}{l}\chi_{(d f=1)}^{2}= \\
0.282\end{array}$ & 0.596 & $\begin{array}{l}\chi_{(d f=19)}^{2}= \\
4.025\end{array}$ & $0.045^{*}$ \\
\hline $\begin{array}{l}\text { Sample humidity } \\
(\%)\end{array}$ & $\begin{array}{l}\chi_{(d f=1)}^{2}= \\
7.270\end{array}$ & 0.07 & $\begin{array}{l}\chi_{(d f=1)}^{2}= \\
0.092\end{array}$ & 0.762 & $\begin{array}{l}\chi_{(d f=1)}^{2}= \\
1.664\end{array}$ & 0.197 & $\begin{array}{l}\chi_{(d f=19)}^{2}= \\
2.724\end{array}$ & 0.099 \\
\hline $\begin{array}{l}\text { Macropore drainable } \\
\text { porosity (\%) }\end{array}$ & $\begin{array}{l}\chi_{(d f=1)}^{2}= \\
6.632\end{array}$ & $0.010^{*}$ & $\begin{array}{l}\chi_{(d f=1)}^{2}= \\
0.060\end{array}$ & 0.806 & $\begin{array}{l}\chi_{(d f=1)}^{2}= \\
0.282\end{array}$ & 0.595 & $\begin{array}{l}\chi_{(d f=19)}^{2}= \\
1.742\end{array}$ & 0.187 \\
\hline $\begin{array}{l}\text { Micropore field } \\
\text { capacity (\%) }\end{array}$ & $\begin{array}{l}\chi_{(d f=1)}^{2}= \\
4.879\end{array}$ & $0.027 *$ & $\begin{array}{l}\chi_{(d f=1)}^{2}= \\
0.000\end{array}$ & 0.997 & $\begin{array}{l}\chi_{(d f=1)}^{2}= \\
1.498\end{array}$ & 0.221 & $\begin{array}{l}\chi_{(d f=19)}^{2}= \\
0.547\end{array}$ & 0.459 \\
\hline
\end{tabular}

(B)

\begin{tabular}{lllll}
\hline Variable & Shaded coffee & Sun Coffee & With ants & Without ants \\
\hline
\end{tabular}




\begin{tabular}{lllll}
\hline $\begin{array}{l}\text { Length of the seedling (cm) } \\
\text { Length of the seedling from main root }\end{array}$ & $33.1 \pm 8.5$ & $36.9 \pm 6.9 *$ & $33.9 \pm 7.2$ & $36.1 \pm 8.4$ \\
tip (cm) & $19.2 \pm 6.8$ & $21.7 \pm 5.9 *$ & $19.3 \pm 5.3$ & $21.5 \pm 7.4$ \\
Plant dry weight (g) & $1.1 \pm 1.1$ & $1.5 \pm 1.3$ & $1.1 \pm 0.9$ & $1.5 \pm 1.4$ \\
Root dry weight (g) & $0.8 \pm 0.4$ & $1.0 \pm 0.4 *$ & $0.9 \pm 0.4$ & $1.0 \pm 0.4$ \\
Stem diameter (mm) & $1.2 \pm 0.7$ & $1.6 \pm 1.1$ & $1.3 \pm 0.8$ & $1.4 \pm 1.0$ \\
T1 infiltration (ml) & $73.2 \pm 12.2$ & $71.3 \pm 14.8$ & $71.8 \pm 13.4$ & $72.6 \pm 13.7$ \\
T2 infiltration (ml) & $15.0 \pm 12.4$ & $23.1 \pm 18.5 *$ & $19.6 \pm 16.6$ & $18.6 \pm 15.9$ \\
Apparent density (g.cc $\left.{ }^{-1}\right)$ & $0.8 \pm 0.1$ & $0.9 \pm 0.2$ & $0.9 \pm 0.1$ & $0.9 \pm 0.1$ \\
Total porous space (\%) & $61.0 \pm 4.0$ & $61.7 \pm 6.9$ & $61.3 \pm 5.6$ & $61.5 \pm 5.7$ \\
Sample humidity (\%) & $41.6 \pm 5.7$ & $38.9 \pm 6.6$ & $40.4 \pm 6.8$ & $40.1 \pm 5.7$ \\
Macropore drainable porosity (\%) & $18.0 \pm 5.8$ & $20.9 \pm 7.9 *$ & $19.4 \pm 7.3$ & $19.6 \pm 6.8$ \\
Micropore field capacity (\%) & $43.0 \pm 5.1$ & $40.8 \pm 5.7 *$ & $41.9 \pm 6.1$ & $41.9 \pm 5.0$
\end{tabular}

366

372 Table 3. LMM deviance analysis of plant growth variables as the experiment progressed 373 (six measurements) $(*)$ : Significant difference at the 0.05 level threshold.

\begin{tabular}{|c|c|c|c|c|}
\hline \multirow[t]{2}{*}{ Factor } & \multicolumn{2}{|l|}{ Stem diameter } & \multicolumn{2}{|c|}{$\begin{array}{l}\text { Seedling length of the } \\
\text { plant }\end{array}$} \\
\hline & Statistics & p-value & Statistics & p-value \\
\hline Land use & $\chi_{(d f=1)}^{2}=2.290$ & 0.130 & $\chi_{(d f=1)}^{2}=0.739$ & 0.0390 \\
\hline Presence of E. ruidum sp. 2 & $\chi_{(d f=1)}^{2}=0.971$ & 0.324 & $\chi_{(d f=1)}^{2}=4.212$ & $0.040^{*}$ \\
\hline Time & $\begin{array}{l}\chi_{(d f=5)}^{2}= \\
740.603\end{array}$ & $<2 \mathrm{e}-16 *$ & $\begin{array}{l}\chi_{(d f=5)}^{2}= \\
3024.426\end{array}$ & $<2 \mathrm{e}-16^{*}$ \\
\hline Farm & $\chi_{(d f=19)}^{2}=15.73$ & 0.227 & $\begin{array}{l}\chi_{(d f=19)}^{2}= \\
27.458\end{array}$ & $0.007 *$ \\
\hline Land use*Presence of E. ruidum sp. 2 & $\chi_{(d f=1)}^{2}=3.19$ & 0.073 & $\chi_{(d f=1)}^{2}=0.936$ & 0.333 \\
\hline Land use*Time & $\chi_{(d f=5)}^{2}=9.079$ & 0.106 & $\begin{array}{l}\chi_{(d f=5)}^{2}= \\
21.307\end{array}$ & $0.0007 *$ \\
\hline Presence of E. ruidum sp. $2 *$ Time & $\chi_{(d f=5)}^{2}=0.881$ & 0.972 & $\chi_{(d f=5)}^{2}=3.132$ & 0.679 \\
\hline Land use*Time*Presence of E. ruidum sp. 2 & $\chi_{(d f=5)}^{2}=1.811$ & 0.875 & $\chi_{(d f=5)}^{2}=1.515$ & 0.911 \\
\hline
\end{tabular}

In the LMM the deviance analysis to determine which of the variables were affected by land use and time as the experiment progressed (six measurements in total in three months) confirmed that ant presence did not influence stem diameter but, together with the factor 'farm', had a positive effect on seedling length $(\mathrm{p}<0.05)$ (Table 3$)$. 
Seedling measurements were influenced by the activity exhibited by the E. ruidum

376 sp. 2 colonies present in the treatment EUs. In the eight treatment EUs that remained active 377 until the end of the experiment in shaded coffee plantations, the presence of E. ruidum sp. 2 378 had a significant positive effect both on the total length of the plant (mean \pm SD: $20.8 \pm 3.9$ $379 \mathrm{~cm} v s .15 .3 \pm 2.5 \mathrm{~cm}$ ) and on the length from the main root tip (mean $\pm \mathrm{SD}: 35.8 \pm 4.6 \mathrm{~cm}$ 380 vs. $28.2 \pm 4.4 \mathrm{~cm}$ ) (Table 4 and Fig. 6). A similar significant positive effect due to the 381 presence of E. ruidum sp. 2 was observed on the stem diameter (mean \pm SD: $2.1 \pm 1.0 \mathrm{~cm}$ 382 vs. $0.7 \pm 0.6 \mathrm{~cm}$ ) in the six treatment EUs still active at the end of the experiment in sun 383 coffee plots (Table 4). Moreover, micropore field capacity was significantly higher in 384 presence of $E$. ruidum sp. 2 colonies in shaded coffee (mean \pm SD: $43.4 \pm 3.1$ vs. $39.7 \pm$ 385 3.1) (Table 4).

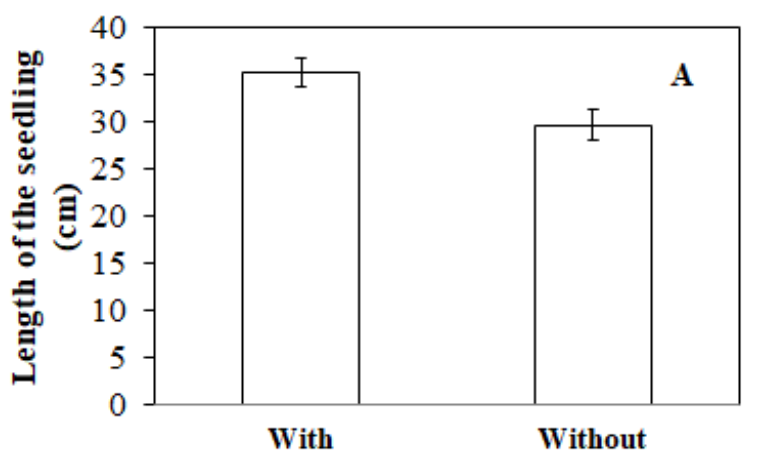

Ectatomma ruidum sp. 2

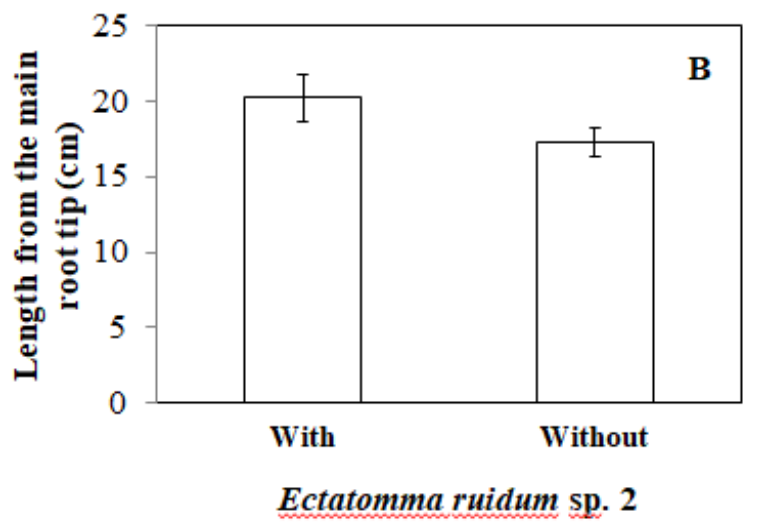

386

387

388

389

390

391

392

393

394

395

Fig. 6. Comparison of two plant growth variables in shaded coffee plots. The bar on the left represents the eight EUs with E. ruidum sp. 2 colonies that were active until the end of the experiment and the bar on the right the 30 EUs without E. ruidum sp. 2 colonies: A) Length of the seedling, B) Length of the seedling from the main root tip. Vertical bars show error values.

Table 4. Comparison (Student- $t$ test) between theoretical (null hypothesis) and observed data obtained for four variables recorded in the 14 EUs with E. ruidum sp. 2 colonies presenting activity until the end of the experiment ( 6 in sun coffee, 8 in shaded coffee).

\begin{tabular}{lllll}
\hline Variable & Land use & Theoretical $\boldsymbol{t}$ & Observed $\boldsymbol{t}$ & $\boldsymbol{p}$ \\
\hline Length from the main root tip & Shaded & 2.14 & 3.38 & 0.0045
\end{tabular}




\begin{tabular}{lllll} 
Seedling length & Shaded & 2.14 & 3.40 & 0.0043 \\
Micropores field capacity & Shaded & 2.14 & 2.37 & 0.0325 \\
Stem diameter & Sun & 2.23 & 2.95 & 0.0144 \\
\hline
\end{tabular}

396

\section{4 | DISCUSSION}

398

To our knowledge, this is the first controlled field experiment that quantifies the contribution of a dominant hunting Ectatomminae species to the ecosystem function of bioturbation, soil physical properties and coffee plant development in Andean agroecosystems. Although multiple factors may affect the performance of artificially added colonies in a field experiment, the evidence provided in this study supports that ants actually play a prominent role in vertical movement of soil in agroecosystems. Even though it was a field experiment carried out in real agroecosystems, it aimed to control several factors such as the size (demography) of the added colonies, food and water supply, area of the enclosures, location of the treatment and control EUs, and standardized conditions of coffee seedlings planted in the EUs, for which we consider our results rather conservative.

\subsection{Bioturbation and physical properties of the soil}

As expected, our data confirmed that colonies of E. ruidum sp. 2 removed high quantities of soil during the first steps of nest excavation, suggesting that this species can actually be considered as a functional agent providing ecosystem support service to soils in Andean tropical agroecosystems, especially when considering its natural history. In the coffee plantations where our experiments were performed, each of the 14 persistently active colonies of E. ruidum sp. 2 removed an average of $228.8 \mathrm{~g}$ dry soil during the 66 days of the experiment. However, for the full complement of the 60 colonies used in this study, the average soil removal fell to slightly less than half this value $(104.4 \mathrm{~g}$, that is, about $1.6 \mathrm{~g}$ day $^{-1}$ colony $^{-1}$ ) providing perhaps a more realistic estimate of the global bioturbation impact of this species at the population level as it takes into consideration both the variability in activity among the colonies and the potential disappearance of several of them, two parameters which resulted relatively high in our control field conditions. The highest soil 
424 removal occurred at the beginning of the experiment, that is, when new nests were

425 excavated by E. ruidum sp. 2. Adding ant colonies to the soil could artificially stimulate the 426 digging activity of the ants, which was higher during the first week, as expected, and very 427 limited after the fifth week (Table 1; Fig. 5). The density of the E. ruidum sp. 2 colonies 428 found in paddocks adjacent to our study coffee zone has previously been estimated between 429568 and 1,945 nests ha ${ }^{-1}$ in shaded and sun cattle pastures, respectively (Santamaría et al., 430 2009). Both using the same nest density estimate for coffee plantations and considering the 431 excavation of one nest per colony per year, as known to occur in Pognomyrmex badius (see 432 Tschinkel 2015), a conservative estimate of the cumulative bioturbation impact of $E$. 433 ruidum sp. 2 in Andean coffee plantations during the two months of digging activity can be 434 calculated at between 59.3 and $203.1 \mathrm{~kg}$ dry soil ha $^{-1}$ (between 0.9 and $3.1 \mathrm{~kg}$ dry soil ha ${ }^{-1}$ 435 day $^{-1}$ over 66 days), a quite important impact despite both the limited period of activity and 436 the very restrictive natural conditions. be considered. First, extremely high nest densities $\left(>5,000\right.$ nests $\left.^{-1}\right)$ can be found in 440 various other regions (Schatz \& Lachaud, 2008), suggesting that the global bioturbation 441 impact of E. ruidum sp. 2 could be much higher and could deeply impact its habitat. In 442 southeastern Mexican coffee plantations, for example, where densities of 5,900 to 11,500 443 nests ha ${ }^{-1}$ have been reported (Schatz \& Lachaud, 2008), the global bioturbation impact 444 could be conservatively estimated at around 9.3 to $18.2 \mathrm{~kg} \mathrm{ha}^{-1}$ day $^{-1}$ during the period of 445 nest excavation activity, that is, an impact roughly equivalent to that of much more 446 populous species such as A. barbigula in arid soils of Australia (approximately $9.2 \mathrm{~kg} \mathrm{ha}^{-1}$ 447 day $^{-1}$ ) (Eldridge \& Pickard, 1994). Second, the assumption of only one nest excavated by 448 colony is probably also underestimated, at least in the study zone. Additional studies on this 449 ant species in coffee plantations in the Andean region (Quevedo Vega, 2015; Berrod, 2017; 450 Santamaría, 2017; CS, unpubl. data) suggest that E. ruidum sp. 2 presents both a high nest 451 turnover and a local polydomy (several nests for one ant colony), two factors promoting the 452 construction of numerous new nests during each climatic season (annual bimodal 453 precipitation). Specifically, we acknowledge that bioturbation caused by E. ruidum sp. 2 is 454 not constant throughout the year, as was also observed by Whitford et al. (1986) for an ant 
455 assemblage in New Mexico. However, the above mentioned local polydomic nesting 456 behaviour, together with the high nesting turnover and the annual wet-dry switching 457 periods in tropical areas, lead us to suggest that this species can enhance vertical soil 458 movement in agroecosystems during a more substantial part of the year than the two 459 months considered previously for our bioturbation estimate. Third, finally, as repetitively 460 noted, the average weight of soil removed could be almost duplicated if considering 461 colonies in more optimal conditions as were the 14 persistently active colonies of our 462 experiment. Better conditions could thus allow to expect a cumulative bioturbation impact 463 of E. ruidum sp. 2 during the two months of digging activity between 130 and $445 \mathrm{~kg}$ dry 464 soil ha ${ }^{-1}$ (between 2.0 and $6.7 \mathrm{~kg}$ dry soil ha ${ }^{-1}$ day $^{-1}$ over 66 days), an impact equivalent to 465 that obtained in Sweden for the combined bioturbation of both L. niger and F. exsecta over 466 a full-year (300-400 $\mathrm{kg} \mathrm{ha}^{-1} \mathrm{y}^{-1}$; see Persson et al., 2007).

467

468 469 470 could be due to the fact that, over a short time span, nest construction activity is not 471 affecting these properties through the first $10 \mathrm{~cm}$ profile level. The architecture of $E$. 472 ruidum sp 2. nests (Santamaría Velasco \& Salas Quinchucua, 2014; Poteaux et al., 2015) 473 could partially explain these results as the entrance is a simple hole (3-5 $\mathrm{mm}$ in diameter) 474 followed by a vertical $10-20 \mathrm{~cm}$ long narrow tunnel which leads to chambers (from 3 to 12) 475 distributed over $80 \mathrm{~cm}$ depth in the study area and up to $120 \mathrm{~cm}$ in some regions, depending 476 on the soil type. Although most of the physical properties did not show differences due to 477 the presence of ants, micropore field capacity was five percent higher in the 14 nests that 478 remained active until the end of the experiment compared to EUs without ants (Table 4). 479 Micropores help to retain water in soil, and may release it when there is a potential 480 difference, such as that generated around the roots which can provide a benefit for the 481 growth of the plant (INTAGRI, 2017), particularly during the dry season in the tropical 482 Americas. This benefit provided by E. ruidum sp. 2 is similar to that found in Martinique 483 (Blanchart et al., 1999), where the activity of earthworms resulted in soils with more than $484 \quad 40 \%$ field capacity which decreased when earthworms were removed. This change in field 485 capacity, together with bioturbation by ants, will contribute to the understanding of the role 
486 of E. ruidum sp. 2 in Andean agroecosystems. Furthermore, even though no evidence was

487 found that nest construction activity by this ant species profoundly impacts the physical

488 properties of soil (except micropore field capacity) within the first $10 \mathrm{~cm}$ from the surface

489 during a short period of two months, any impact at deeper soil levels could eventually

490 affect upper levels over a longer time span.

491

$492 \quad 4.2 \mid$ Seedling growth

493

494 Overall, considering all colonies involved in our experiment, we did not find evidence that 495 the presence of E. ruidum sp. 2 affected the growth of coffee seedlings over the short term. 496 The differences were detected only for land use (Table 2) and not for the presence of ants.

497 Most of the seedlings grew faster in sun than in shaded coffee plantations, a reasonable 498 result that could be explained because the "caturra" coffee variety used here is adapted to 499 grow under sunny conditions and possesses less nodes per branch and less floral buds on 500 the existing nodes when planted in the shade (Arcila et al., 2007; DaMatta \& Rodríguez, 501 2007). Additionally, when seedlings were planted, adult coffee plants were always present 502 in the immediate vicinity of the EUs, providing a degree of protection from the harsh 503 conditions in the open agroecosystems.

504

505

506

507

508

509

510

511

512

513

As the experiment progressed, there were highly significant effects of ant presence on seedling length (but not on stem diameter) (Table 3), which demonstrates that this variable is highly dependent on local conditions, such as farm condition, previous history (grasslands, or cassava or other crops prior to coffee), management and the presence of ant activity. This is supported by the significant "farm" effect and land use-time interaction effect. The variable of stem diameter did not present significantly different results, with the exception of time, maybe because it is a more stable variable which also needed more time to exhibit any treatment effects. The unexpected global lack of a positive effect due to the presence of E. ruidum sp. 2 appeared to be associated with difficulties in the establishment

514 of some colonies and, above all, to the very unequal level of activity among them, which is 515 why the positive effects were found only when considering the colonies that remained 516 active throughout the entire experimental period. Therefore, when considering only 
517 colonies that were always active (Table 4), their presence in the EUs did result in a

518 significant positive effect on various plant growth variables, i.e. total length of the plant and

519 length from the main root tip toward the apical meristem in shaded coffee and stem

520 diameter in sun coffee seedlings.

It should be pointed out that the greatest movement of soil by removal occurred 523 during the first stage of nest establishment whereby nutrients are added to the soil through 524 nutrient cycling. Newly added nutrients likely come from sources such as the prey brought 525 to E. ruidum sp. 2 nests (this hunting species may collect up to 260 million prey ha ${ }^{-1}$ day $^{-1}$ 526 in cacao plantations in Mexico; see Lachaud et al. (1996)) and from corpses of dead 527 nestmates. In our study, limited amounts of prey were provided in order to control the 528 nutrients added (both in treatment and the control EUs). These nutrients could eventually 529 contribute to the seedling growth during the final stage of the experiment, where plants in 530 shaded coffee plots added with E. ruidum sp. 2 that were active throughout the entire 531 experimental period were approximately $4 \mathrm{~cm}$ higher when compared to plants from 532 control EUs in shaded coffee (Fig. 6). This result is consistent with that reported by 533 Wagner \& Nicklen (2010) where Acacia constricta plants benefited from soil nutrients 534 derived from ant nests. Additionally, the result is also consistent with observations in other 535 ants such as Pheidole spp., where $\mathrm{C}, \mathrm{N}, \mathrm{P}$ and $\mathrm{NO}_{3}-\mathrm{N}$ amounts were higher in soil with 536 ants than in those without ants (Shukla et al., 2013). In India, Seema (2016) found 537 evidence that soils with different ant species present the highest $\mathrm{K}$ and $\mathrm{P}$ concentrations, 538 when compared to soils without ants. The results of a previous pilot experiment, conducted 539 under identical conditions as the present study, but in the experimental station of the 540 Universidad del Valle (Cali, Colombia) over an area of about $60 \mathrm{~m}^{2}$ (Rondón, 2017), 541 demonstrated that coffee seedlings grew significantly faster in length and diameter in the 542 presence of E. ruidum sp. 2 colonies. However, control EUs at each of the sites did not 543 allow detection of any differences, suggesting that over a short time scale, ant excavation 544 activity does not affect neighbouring coffee seedlings, especially if colonies are weak and 545 almost do not perform excavation activity. This is supported by the fact that more than two 546 thirds of the colonies (46 from the 60 ant colonies) liberated in treatment EUs had to 547 survive harsh conditions such as being enclosed in a very small area, competing with 
548 already established aggressive ants (namely Wasmannia auropunctata), and depending on

549 resources provided by the researchers. Considering that, even under these unfavorable

550 conditions our data clearly showed that E. ruidum sp. 2 contributes to supporting

551 ecosystem services in tropical agroecosystems through bioturbation exhibited during nest

552 construction, it is highly probable that their impact, both on soil physical characteristics

553 and plant growth, would be higher under less restrictive, natural conditions.

554

555 Finally, from our data we conclude that excavating colonies of E. ruidum sp. 2 do cause

556 significant changes in bioturbation (through soil particle removal), and in only one of the

557 soil physical properties measured. Additionally, we conclude that coffee seedlings grew

558 faster when they were close to burrowing colonies of this ant species. These results

559 support the idea that E. ruidum sp.2 is a functionally important soil agent in Neotropical

560 agroecosystems.

561

562 ACKNOWLEDGEMENTS

563

564 We thank all of the farm owners and colleagues who contributed to the field work, 565 especially Omar Marín, Andrés López, Antonio Velasco and Reynel Paz. Thanks to the 566 Graduate program at Universidad del Valle, Cali, and to Wilmar Torres for statistical 567 support. This Project was financed by the Colciencias Programa Nacional de Ciencias 568 Basicas (Code 110656933821, RC Contract No. 0648-2013), and also received support 569 from the Graduate Program in Biological Sciences at the Universidad del Valle through the 570 Vicerrectoría de Investigaciones de la Universidad del Valle project for international 571 visibility (Code CI 71000), and by the 727- 2015 call to support Colciencias' National 572 Doctoral Candidates.

573

574 REFERENCES

575

576 AntWeb. Available from http://www.antweb.org. Accessed 21 March 2019. 
577 Arcila, P., J., Farfán, V., F., Moreno, B., A., Salazar, G., L. F., \& Hincapié, G., E. (2007).

578 Sistemas de producción de café en Colombia. Chinchiná: Cenicafé.

579 Berrod, L., 2017. Etude de la polydomie chez la fourmi Ectatomma ruidum Roger 580 (Hymenoptera, Formicidae). M. Sci. Thesis, Université Paris 13.

581 Blanchart, E., Albrecht, A., Alegre, J., Duboisset, A., Gilot, C., Pashanasi, B., ... Brussaard, 582 L. (1999). Effects of earthworms on soil structure and physical properties. In P. 583 Lavelle, L. Brussaard \& P. Hendrix (Eds.), Earthworm management in tropical 584 agroecosystems (pp. 149-172), Wallingford, UK: CAB International.

585 Bolton, B., Alpert, G., Ward, P. S., \& Naskrecki, P. (2007). Bolton's catalogue of ants of 586 the world. 1758-2005.Cambridge, MA: Harvard University Press, CD ROM.

587 DaMatta, F., \& Rodríguez, N. (2007). Producción sostenible de cafetales en sistemas 588 agroforestales del Neotrópico: una visión agronómica y ecofisiológica. Agronomía $589 \quad$ Colombiana, 25(1), 113-123.

590 Del Toro, I., Ribbons, R. R., \& Pelini, S. L. (2012). The little things that run the world 591 revisited: a review of ant-mediated ecosystem services and disservices (Hymenoptera: $592 \quad$ Formicidae). Myrmecological News, 17, 133-146.

593 Domínguez-Haydar, Y., \& Armbrecht, I. (2011). Response of ants and their seed removal 594 in rehabilitation areas and forests at El Cerrejón coal mine in Colombia. Restoration 595 Ecology, 19(201), 178-184. https://doi.org/10.1111/j.1526-100X.2010.00735.X 596 Eldridge, D. J. (1993). Effect of ants on sandy soils in semi-arid eastern Australia: Local 597 distribution of nest entrances and their effect on infiltration of water. Australian 598 599 600 601 602 603 604 605 Journal of Soil Research, 31(4), 509-518. https://doi.org/10.1071/SR9930509

Eldridge, D. J., \& Pickard, J. (1994). Effects of ants on sandy soils in semi-arid eastern Australia: II. Relocation of nest entrances and consequences for bioturbation. Australian Journal of Soil Research, 32(2), 323-333. https://doi.org/10.1071/SR9940323

Eldridge, D. J., Whitford, W. G., \& Duval, B. D. (2009). Animal disturbances promote shrub maintenance in a desertified grassland. Journal of Ecology, 97(6), 1302-1310. https://doi.org/10.1111/j.1365-2745.2009.01558.x 
606 Evans, T. A., Dawes, T. Z., Ward, P. R., \& Lo, N. (2011). Ants and termites increase crop 607 yield in a dry climate. Nature Communications, 2(1), 262. https://doi.org/10.1038/ncomms1257

609 Farji-Brener, A. G., \& Werenkraut, V. (2017). The effects of ant nests on soil fertility and 610 plant performance: a meta-analysis. Journal of Animal Ecology, 86(4), 866-877. https://doi.org/10.1111/1365-2656.12672.

FNC (Federación Nacional de Cafeteros). (2010). Área cultivada según exposición solar por departamento. https://www.federaciondecafeteros.org/particulares/es/quienessomos/119 estadisticas historicas.

Folgarait, P. J. (1998). Ant biodiversity and its relationship to ecosystem functioning: a review. Biodiversity and Conservation, 7(9), 1221-1244. https://doi.org/10.1023/A:1008891901953

Fontalvo-Rodríguez, L., \& Domínguez-Haydar, Y. (2009). Ectatomma ruidum (Roger) como indicadora de diversidad de hormigas cazadoras (Hymenoptera: Formicidae) y relación con estructura vegetal en parches de bosque seco del Caribe colombiano. Intropica, 4, 29-39.

Gutierrez-Rapalino, B. P., \& Domínguez-Haydar, Y. (2017). Contribución de Pheidole fallax y Ectatomma ruidum (Hymenoptera: Formicidae) en la dispersión y germinación de semillas en áreas rehabilitadas de la mina de carbón del Cerrejón, Colombia. Revista de Biología Tropical, 65(2), 575-587.

Hölldobler, B., \& Wilson, E.O. (1990). The Ants. Cambridge, USA: Harvard University Press.

INTAGRI. 2017. Propiedades Físicas del Suelo y el Crecimiento de las Plantas. Serie Suelos. Núm. 29. Artículos Técnicos de INTAGRI. México. 5 p.

633 Kovář, P., Kovářová, M., Dostál, P., \& Herben, T. (2001). Vegetation of ant-hills in a 634 mountain grassland: effects of mound history and of dominant ant species. Plant 635 Ecology, 156(2), 215-227. https://doi.org/10.1023/A:1012648615867. 
636 Lachaud, J.-P. (1990). Foraging activity and diet in some neotropical ponerine ants. I.

637 Ectatomma ruidum Roger (Hymenoptera, Formicidae). Folia Entomológica Mexicana, $78,241-256$.

639 Lachaud, J.-P., López-Méndez, J. A., Schatz, B., De Carli, P., \& Beugnon, G. (1996).

640 Comparaison de l'impact de prédation de deux ponérines du genre Ectatomma dans un agroécosystème néotropical. Actes des Colloques Insectes Sociaux, 10, 67-74.

643 plant growth in soils from pine forests and plantations: Effect of invasive red imported 644 fire ants Solenopsis invicta (Buren). Pedobiologia, 49(5), 415-423. https://doi.org/10.1016/j.pedobi.2005.05.002

Lavelle, P., Decaëns, T., Aubert, M., Barot, S., Blouin, M., Bureau, F., ... Rossi, J.-P. (2006). Soil invertebrates and ecosystem services. European Journal of Soil Biology, 42(1), S3-S15. https://doi.org/10.1016/j.ejsobi.2006.10.002

Levings, S.C., \& Franks, N.R. (1982). Patterns of nest dispersion in a tropical ground ant community. Ecology, 63(2), 338-344. https://doi.org/10.2307/1938951

Lobry de Bruyn, L.A., \& Conacher, A.J. (1990). The role of termites and ants in soil modification: a review. Australian Journal of Soil Research, 28(1), 55-93. https://doi.org/10.1071/SR9900055

Lobry de Bruyn, L.A., \& Conacher, A.J. (1994). The bioturbation activity of ants in agricultural and naturally vegetated habitats in semi-arid environments. Australian Journal of Soil Research, 32(3), 555-570. https://doi.org/10.1071/SR9940555

Moreira, A. A., Forti, L. C., Andrade, A. P. P., Boaretto, M. A. C., \& Lopes, J. F. S. (2004). Nest architecture of Atta laevigata (F. Smith, 1858) (Hymenoptera: Formicidae). Studies on Neotropical Fauna and Environment, 39(2), 109-116. https://doi.org/10.1080/01650520412331333756

Persson, T., Lenoir, L., \& Taylor, A. (2007). Bioturbation in different ecosystems at Forsmark and Oskarshamn. SKB Report: R-06-123. https://www.skb.com/publication/1357628/

Philip, J. R. (1957). The theory of infiltration: 4. Sorptivity and algebraic infiltration equations. Soil Science, 84(3), 257-264. 
666 Poteaux, C., Prada-Achiardi, F. C., Fernández, F., \& Lachaud, J.-P. (2015). Diversidade

667 genética e fenotípica no gênero Ectatomma. In: Delabie, J. H. C., Feitosa, R. M.,

668 Serrão, J. E., Mariano, C. S. F., Majer, J. D. (Eds.), As Formigas Poneromorfas do

669 Brasil. Editus, Ilhéus, pp. 127-144.

670 Quevedo Vega, C. J., (2015). Interacciones competitivas y variabilidad en las estrategias de

671 nidificación de Ectatomma ruidum (Formicidae: Ectatomminae). Trabajo de Grado.

672 Cali, Universidad del Valle.

673 R Core Team. (2017). R: A language and environment for statistical computing. R

$674 \quad$ Foundation for Statistical Computing, Vienna, Austria.

675 Richards, P. J. (2009). Aphaenogaster ants as bioturbators: Impacts on soil and slope

676 processes. Earth Science Reviews, 96(1-2), 92-106.

677

678

https://doi.org/10.1016/j.earscirev.2009.06.004

Rondón, M. F. (2017). Efectos de la nidificación de Ectatomma ruidum (Formicidae) sobre

679 propiedades del suelo y plántulas de café. Boletín del Museo de Entomología de la

680

681 Universidad del Valle, 17(2), 54.

682

683

684

685

686

687

688

689

690

691

692

Santamaría, C. (2017). Interacciones entre nidos de Ectatomma ruidum, ¿polidomia o cleptobiosis? Boletín del Museo de Entomología de la Universidad del Valle, 18(1) Supl. 1, 12.

Santamaría, C., Armbrecht, I., \& Lachaud, J.-P. (2009). Nest distribution and food preferences of Ectatomma ruidum (Hymenoptera: Formicidae) in shaded and open cattle pastures of Colombia. Sociobiology, 53(2B), 517-541.

Santamaría Velasco, C. A., \& Salas Quinchucua, C. (2014). Arquitectura de los nidos de la hormiga Ectatomma ruidum Roger (Hymenoptera: Formicidae). Resúmenes 41 Congreso Sociedad Colombiana de Entomología, Cali, Colombia, p. 222.

Schatz, B., \& Lachaud, J.-P. (2008). Effect of high nest density on spatial relationships in two dominant ectatommine ants (Hymenoptera: Formicidae). Sociobiology, 51(3), 623-

693 Seema G., K. (2016). Role of ants genera on induced modification and fertility of soil. 694 International Journal of Life Sciences, A6, 189-191.

695 Shukla, R.K., Rastogi, N., \& Singh, H. (2018). Contribution of the nutrient-enriched ant 696 nest debris soil to growth and yield of Kalmegh (Andrographis paniculata) under 
697 natural and experimental field conditions. Biological Agriculture \& Horticulture, 698 34(3), 173-185. https://doi.org/10.1080/01448765.2017.1408492

699 Tschinkel, W. R. (2015). Biomantling and bioturbation by colonies of the Florida harvester 700 ant, Pogonomyrmex badius. PLoS One, 10(3): e0120407.

701 https://doi.org/10.1371/journal.pone.0120407

702 Tschinkel, W. R., \& Seal, J. N. (2016). Bioturbation by the fungus-gardening ant,

703 Trachymyrmex septentrionalis. PloS One, 11(7): e0158920.

704 https://doi.org/10.1371/journal.pone.0158920

705 Wagner, D., \& Nicklen, E. F. (2010). Ant nest location, soil nutrients and nutrient uptake 706 by ant-associated plants: does extrafloral nectar attract ant nests and thereby enhance 707 plant nutrition? Journal of Ecology, 98(3), 614-624. https://doi.org/10.1111/j.1365$708 \quad 2745.2010 .01640 . x$

709 Ward, P. S. (2009). Taxonomy, phylogenetics, and evolution. In L. Lach, C. Parr \& K. L. 710 Abbot (Eds.), Ant ecology (pp. 3-17), Oxford: Oxford University Press,

711 Whitford, W. G., Schaefer, D., \& Wisdom, W. (1986). Soil movement by desert ants. The 712 Southwestern Naturalist, 31(2), 273-274.

713

714 